\title{
Pengolahan Nitrifikasi Limbah Amonia dan Denitrifikasi Limbah Fosfat dengan Biofilter Tercelup
}

\section{Processing Ammonia Nitrification and Phosphat Denitrification Wastewater with Submerged Biofilter}

\author{
ARYSCA WISNU SATRIA ${ }^{1}$, MERZA RAHMAWATI ${ }^{1}$, AGUS PRASETYA ${ }^{2}$ \\ ${ }^{1}$ Institut Teknologi Sumatera, Lampung Selatan, Lampung \\ ${ }^{2}$ Universitas Gadjah Mada, Sleman, D.I. Yogyakarta \\ Email : arysca.wisnu@tk.itera.ac.id
}

\begin{abstract}
Water pollution is a problem that often arises and gives a serious impact to the environment. Therefore, it should be reduced by conventional methods or modern methods. The submerged biofilter is a biological waste treatment plant that utilizing microorganisms grown in a packing medium. The advantages of submerged biofilter as a waste treatment plant are easy to use and low energy consumption so the operational cost is cheaper. This study aims to determine the operational parameters of the submerged biofilter and to develop a model that can be used to estimate the rate of elimination of each pollutant using nitrification reactor for ammonia and denitrification reactor for phosphate. The experiments were conducted with draining the wastewater in a cylindrical bio-filter column in which the hight is $90 \mathrm{~cm}$. At first, the microorganism was grown for two weeks with the residence time of one day. Furthermore, the wastewater removals are conducted with hydraulic loading rate $(H L R)$ variation of $0.44 ; 0.55 ; 0.74 ; 1.11$; 1.66; 2.21; and $3.32 \mathrm{m3} / \mathrm{m} 2 /$ day. Then the effluent from the outlet is analyzed using UV-Vis Spectrophotometer. The results showed that the optimum ammonia and phosphate removal was obtained in $0.44 \mathrm{m3} / \mathrm{m} 2 /$ day for ammonia removal and $1.66 \mathrm{m3} / \mathrm{m} 2 /$ day for phosphate removal. While the removal of ammonia and phosphate percentage from both conditions are $97.41 \%$ and $27.16 \%$ respectively. The changes of HLR will give an effect on substrate reduction rate (SRR), and the percentage of substrate removal. The model developed based on efficiency factors presented a good approach to represent the concentration of substrate effluent at various HLR.
\end{abstract}

Keywords: wasteswater, nitrification, denitrification, submerged biofilter

\begin{abstract}
ABSTRAK
Pencemaran air merupakan permasalahan yang sering muncul dan berpengaruh serius pada lingkungan. Oleh karena itu, perlu dilakukan usaha yang berkelanjutan untuk dapat mengurangi dampak dari pencemaran tersebut, baik dengan cara-cara konvensional maupun inovasi teknologi terbaru. Biofilter tercelup (submerged biofilter) adalah suatu alat pengolah limbah secara biologi dengan memanfaatkan mikroorganisme yang ditumbuhkan dalam media packing di dalamnya. Kelebihan penggunaan biofilter tercelup sebagai alat pengolah air limbah adalah pengelolaannya yang mudah dan konsumsi energi yang rendah sehingga biaya operasionalnya murah. Penelitian ini bertujuan untuk mengetahui parameter operasional biofilter tercelup dan mengembangkan model untuk memperkirakan laju penyisihan setiap polutan menggunakan reaktor nitrifikasi untuk limbah amonia dan reaktor denitrifikasi untuk fosfat. Percobaan dilakukan dengan mengalirkan limbah pada sebuah kolom biofilter berbentuk silinder dengan ketinggian $90 \mathrm{~cm}$. Pada mulanya mikroorganisme ditumbuhkan dengan mengalirkan limbah selama dua minggu dengan waktu tinggal cairan satu hari. Selanjutnya dilakukan penyisihan limbah dengan variasi kecepatan beban hidrolik (HLR) sebesar 0,$44 ; 0,55 ; 0,74 ; 1,11 ; 1,66 ; 2,21$; dan $3,32 \mathrm{~m}^{3} / \mathrm{m}^{2} /$ hari. Effluent dari keluaran reaktor kemudian dianalisis menggunakan Spektrofotometer UV-Vis. Hasil penelitian menunjukkan bahwa kondisi optimum penyisihan amonia dan fosfat adalah $0,44 \mathrm{~m}^{3} / \mathrm{m}^{2} /$ hari untuk penyisihan amonia dan $1,66 \mathrm{~m}^{3} / \mathrm{m}^{2} /$ hari untuk penyisihan fosfat. Persentase removal amonia dan fosfat dari kedua kondisi tersebut berturut-turut sebesar $97,41 \%$ dan $27,16 \%$. Perubahan HLR berpengaruh terhadap kecepatan penyisihan limbah (SRR), dan persentase limbah tersisihkan. Model yang dikembangkan berdasarkan faktor efisiensi memberikan hasil yang cukup baik untuk merepresentasikan besarnya konsentrasi effluent limbah pada berbagai variasi HLR
\end{abstract}

Kata kunci: limbah cair, nitrikasi, denitrifikasi, biofilter tercelup 


\section{PENDAHULUAN}

\subsection{Latar Belakang}

Limbah cair atau yang biasa disebut air limbah merupakan salah satu jenis limbah yang keberadaannya sering menjadi masalah dalam kehidupan masyarakat. Sifatnya yang memiliki mobilitas cukup tinggi mengakibatkan limbah jenis ini dengan mudah mencemari lingkungan, khususnya perairan. Menurut Peraturan Pemerintah No 82 Tahun 2001 tentang Pengelolaan Kualitas Air dan Pengendalian Pencemaran Air, menjelaskan bahwa tidak diperkenankan membuang limbah cair ke dalam perairan atau tanah, kecuali mendapat izin tertulis dari bupati/wali kota terkait dan berdasarkan hasil pengkajian.

Limbah cair yang berasal dari industri umumnya mengandung senyawa kimia, logam berat, bahan berbahaya, dan beracun (B3), serta berbagai senyawa organik dalam konsentrasi yang tinggi. Untuk limbah cair dari pemukiman penduduk (domestik) komponen terbesarnya berupa padatan, baik dalam bentuk terlarut (dissolved solid) atau tersuspensi (suspended solid). Padatan ini mengandung zatzat organik, seperti: karbohidrat, protein, lemak, dan minyak, maupun zat anorganik, yang berupa: kalsium, klorida, besi, dan lain-lain.

Limbah organik yang biasanya tersusun oleh karbon, hidrogen, oksigen, nitrogen, fosfor, sulfur, dan mineral lainnya yang masuk ke dalam perairan dalam bentuk padatan yang terendap, koloid, tersuspensi maupun terlarut. Nitrogen dan fosfor (nutrien perairan) merupakan dua jenis bahan pencemar yang sering menjadi perhatian karena pada kadar tertentu justru menimbulkan dampak yang kurang baik bagi beberapa makhluk hidup. Nitrogen dan fosfor dalam air limbah biasanya berada dalam bentuk amonia, nitrat dan fosfat. Kadar ketiga pencermar ini jika berlebihan dapat menyebabkan terjadinya pertumbuhan alga yang cepat di perairan (algae bloom) sehingga berakibat menggeser keseimbangan ekosistem. Kandungan amonia yang tinggi dalam perairan dapat juga bersifat racun bagi organisme yang ada di perairan.

Menurut Dombrowski(1) rata-rata konsentrasi $\mathrm{NH}_{4}-\mathrm{N}$ dan total $\mathrm{N}$ di dalam limbah cair domestik masing-masing berkisar antara 44,5-75,9 mg/l dan 74,5-103,5 mg/l. Adapun konsentrasi P total berkisar antara 11,7-18,8 mg/l. Sementara itu, menurut Permen Lingkungan Hidup dan Kehutanan Nomor P.68 Tahun 2016(2) tentang Baku Mutu Air Limbah Domestik mensyaratkan bahwa batas konsentrasi amonia untuk limbah domestik yang dizinkan untuk dibuang adalah $10 \mathrm{mg} / \mathrm{L}$ (ppm).

\subsection{Tinjauan Pustaka}

Penanganan limbah cair pada dasarnya dapat dilakukan dengan cara fisika, kimia maupun biologi. Pengolahan limbah secara fisik dan kimia biasanya memerlukan biaya yang relatif cukup mahal dan kadang masih menimbulkan masalah baru dari hasil pengolahan. Adapun pengolahan secara biologi sering digunakan sebagai alternatif cara yang paling efektif dan murah karena karena hasilnya tidak memerlukan perlakuan (treatment) khusus(3). $^{(3)}$.

Salah satu teknik pengolahan limbah secara biologi yang memanfaatkan kemampuan mikroorganisme adalah biofilter tercelup. Biofilter tercelup merupakan alat pengolahan limbah cair dengan menggunakan mikroorganisme yang ditumbuhkan dalam suatu media biakan (attached culture) dan cairan yang diolah tersebut dilewatkan melintasi media tersebut secara kontinyu ${ }^{(4,5)}$.

Penggunaan media packing selain berfungsi sebagai filter untuk menyisihkan bahan yang tersuspensi, juga untuk tempat tumbuhnya mikroorganisme. Adanya packing tersebut menyebabkan mikroorganisme tumbuh dan melekat atau membentuk lapisan tipis (biofilm) pada permukaan media(6).

Pemanfaatan utama dari reaktor bed biologis ini dapat sebagai secondary treatment (carbon removal atau simultaneous carbon and nitrogen removal) dan tertiary treatment (nitrifikasi dan postdenitrifikasi) ${ }^{(7)}$. Proses pengolahan limbah cair dengan sistem biofilter dapat dilakukan secara aerobik, anaerobik atau gabungan proses anaerob-aerob. Proses aerobik dilakukan dalam kondisi adanya oksigen terlarut di dalam reaktor air limbah, dan proses anaerobik dilakukan tanpa adanya oksigen dalam reaktor air limbah.

Proses kombinasi aerob-anaerob biasanya digunakan untuk menyisihkan (removal) kandungan nitrogen di dalam air limbah. Untuk removal nitrogen, pada kondisi aerobik terjadi proses nitrifikasi, yaitu amonia diubah menjadi nitrat $\left(\mathrm{NH}^{4+} \rightarrow \mathrm{NO}_{3}{ }^{-}\right)$dan pada kondisi anaerobik (anoxic) terjadi proses denitrifikasi, yaitu nitrat yang terbentuk diubah menjadi gas nitrogen $\left(\mathrm{NO}_{3}{ }^{-} \rightarrow \mathrm{N}_{2}\right)^{(8)}$.

Kombinasi proses aerob-anaerob juga dapat menghilangkan fosfor maupun BOD/COD secara bersamaan dengan baik. Selama berada pada kondisi aerob, senyawa fosfor terlarut akan diambil oleh bakteri/mikroorganisme dan disintesis menjadi polifosfat dengan menggunakan energi yang dihasilkan oleh proses oksidasi senyawa BOD/COD. Sementara pada kondisi anaerob, senyawa fosfor anorganik yang ada dalam sel-sel mikroorganisme akan keluar sebagai akibat hidrolisis senyawa fosfor, 
sedangkan energi yang dihasilkan digunakan untuk menyerap BOD (senyawa organik) yang ada dalam air limbah ${ }^{(9)}$.

Cara yang dilakukan untuk mengolah air limbah dengan kandungan fosfat adalah melalui mekanisme enhance biological phosphorous removal (EBPR). Presipitasi fosfat dan pembuangannya dari limbah cair terjadi karena aktivitas mikrobia dalam tanki aerasi. Pada tahap awal tanki aerasi, aktivitas mikrobia menyebabkan $\mathrm{pH}$ turun sehingga melarutkan komponen fosfat. Pada akhir tanki aerasi, tejadi peningkatan $\mathrm{pH}$ yang menyebabkan presipitasi fosfat dan penggabungan komponen fosfat ke dalam endapan. Proses ini terjadi dalam lapisan biofilm bersamaan degan proses denitrifikasi senyawa nitrogen ${ }^{(10)}$.

Uji coba pengguanaan biofilter untuk mendegradasi bahan-bahan organik polutan dalam air limbah industri dengan kombinasi anaerob dan aerob berkapasitas 10-16 $\mathrm{m}^{3} /$ hari telah dilakukan oleh BPPT(11) menggunakan media plastik sarang tawon. Proses yang dilakukan, mula-mula sistem dioperasikan secara anaerob, kemudian kombinasi anaerob-aerob (khusus untuk tangki biofilter terakhir). Percobaan tersebut dilakukan dengan memvariasikan HRT total 16 - 24 jam. Hasil yang dicapai menunjukkan bahwa pada proses anaerob dengan laju alir $10-16 \mathrm{~m}^{3} /$ hari setelah proses berjalan 2 bulan diperoleh efisiensi penurunan BOD $89,4 \%$, COD $88,2 \%$ dan TSS 94\%.

Ferraz, et al.(12) juga meneliti pemanfaatan biofilter tercelup untuk penyisihan (removal) BOD, COD, TSS, dan TAN landfill leachate dengan mengambil tiga parameter perlakuan rasio volumetrik, yaitu $0 \%, 2 \%$, dan $5 \%$ pada waktu tinggal 24 jam. Pada rasio volumetrik $2 \%$ diperoleh hasil tebaik untuk menyisihkan masingmasing polutan, yaitu $98 \%$ BOD, $80 \%$ COD, $90 \%$ TSS, dan $90 \%$ TAN. Sementara itu Mehmet ${ }^{(13)}$ meneliti pemanfaatan biofilter tercelup pada laboratorium menggunakan sistem sirkulasi limbah udang. Profil removal amonia beban pemasukan limbah sebesar 2,65; 5,52; 7,91; dan $10,94 \mathrm{~g} /$ hari dievaluasi, menunjukan peningkatan persentase removal amonia kemudian mengalamai penurunan pada hari berturut-turut $66,62,50$, dan 35 .

Sementara itu, pada penelitian ini digunakan biofilter tercelup dengan kombinasi sistem downflow dan upflow menggunakan kolom pipa silindris sehingga dapat ditinjau kehandalannya menggunakan model matematis.

\subsection{Tujuan Penelitian}

Penelitian ini bertujuan untuk mengetahui parameter operasional biofilter tercelup dan mengembangkan model matematis yang dapat memperkirakan laju penyisihan setiap polutan menggunakan reaktor nitrifikasi untuk limbah amonia dan reaktor denitrifikasi untuk limbah fosfat dari limbah kolam ikan.

\section{BAHAN DAN METODE}

\subsection{Bahan}

Bahan yang digunakan dalam penelitian ini adalah limbah cair perikanan mengandung amonia dan fosfat. Limbah cair ini sebelumnya diukur konsentrasi kedua polutan tersebut sebagai data awal konsentrasi komponen limbah yang akan diolah. Selain itu, ke dalam limbah juga ditambahkan metanol sebagai sumber karbon dan sodium bikarbonat untuk mengatur $\mathrm{pH}$. Sementara untuk media packing bioball dibeli dari pasaran dengan mengambil spesifikasi dari tinjauan literatur.

\subsection{Metode}

Penelitian ini dilaksanakan di kebun percobaan Taman Hortikultura, Dinas Pertanian Provinsi Lampung selama bulan Juli - Oktober 2017. Alat yang digunakan berupa kolom pipa dengan diameter 5 inci sepanjang $90 \mathrm{~cm}$ yang berisi packing bioball. Kolom biofilter dibuat dua jenis, yaitu biofilter aerob dan biofilter anaerob. Biofilter aerob berfungsi untuk menyisihkan polutan amonia melalui proses nitrifikasi, sedang biofilter anaerob untuk menyisihkan polutan fosfat.

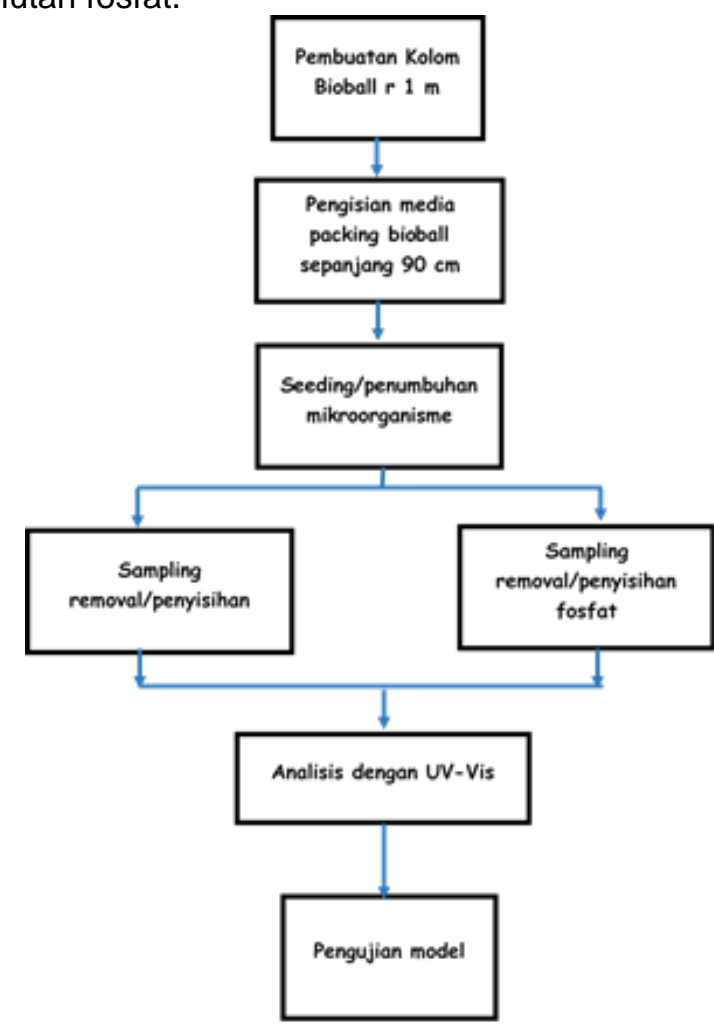

Gambar 1. Diagram proses alur kerja 
Limbah dari kolam ditampung dalam bak penampung terlebih dahulu untuk menstabilkan limbah sebelum dialirkan ke dalam kolom biofilter. Dari bak penampung tersebut, aliran dibagi menjadi dua yaitu ke dalam kolom biofilter anaerob dan kolom biofilter aerob. Ke dalam masing-masing kolom reaktor tersebut dialirkan limbah selama dua minggu dengan waktu tinggal (hidraulic retention time/HRT) satu hari untuk pertumbuhan mikroorganisme.

Dalam masing-masing reaktor selanjutnya dilakukan variasi kecepatan beban hidraulik (hidraulic loading rate/HLR) aliran limbah, yaitu: 0,$44 ; 0,55 ; 0,74 ; 1,11 ; 1,66 ; 2,21$ dan 3,32 $\mathrm{m}^{3} / \mathrm{m}^{2} /$ hari. Selanjutnya dari masing-masing HLR tersebut dilakukan analisis konsentrasi akhir limbah limbahnya menggunakan Spektrofotometer UV-Vis. Masing-masing HLR akan diulang sebanyak tiga kali sampai terlihat polanya steady. Hasil dari masing-masing sampel tersebut selanjutnya dilakukan analisis modeling untuk menentukan kehandalan masing-masing reaktor dalam menyisihkan limbah. Model yang digunakan adalah faktor efisiensi, seperti yang dikembangkan oleh Grady dan McCarthy $(14,15)$, yaitu perbandingan flux substrat masuk dan keluar permukaan cairan-biofilm dengan kecepatan pemanfaatan substrat secara keseluruhan per unit dari luas penampang biofilter.

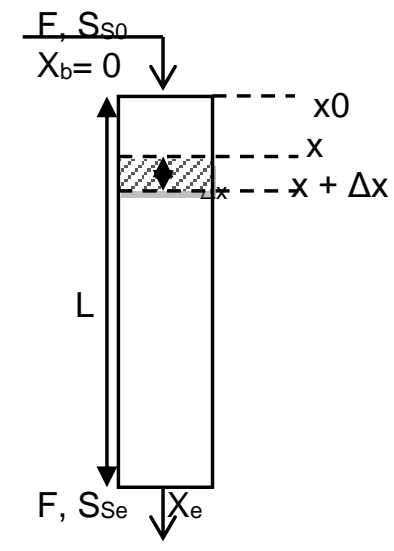

Gambar 2. Aliran substrat pada biofilter

Persamaan neraca massa substrat pada fase cair pada elemen volume biofilter Gambar 2 adalah:

$$
\begin{aligned}
& \text { F. }\left.S_{S a}\right|_{x}-\left.F \cdot S_{S a}\right|_{x+\Delta x}-\eta_{e}\left(\frac{q H, S_{S a}}{K_{s}+S_{S a}}\right) \cdot X_{b}, a s \cdot A c \cdot \Delta x \cdot L_{f} \\
& -\left(\frac{q H, S_{S a}}{K_{S}+S_{S a}}\right) \cdot f_{a c} \cdot \Delta x \cdot A c \cdot Y_{x / s}\left(S_{S 0}-S_{S a}\right)=0
\end{aligned}
$$

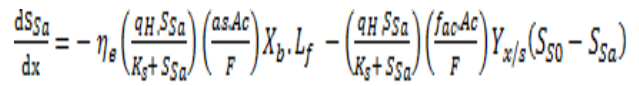

Persamaan (2) term ketiga adalah degradasi substrat oleh attached biomass, sedangkan term keempat adalah degradasi oleh suspended biomass. Adapun penjelasan dari masing-masing parameter berserta nilainya tersaji dalam Tabel 1 dan Tabel 2.

\begin{tabular}{|c|c|c|}
\hline Lambang & Arti & Satuan \\
\hline$F$ & $\begin{array}{l}\text { kecepatan aliran } \\
\text { volume limbah }\end{array}$ & $m^{3} / h a r i$ \\
\hline$S_{S a}$ & $\begin{array}{l}\text { konsentrasi air limbah } \\
\text { pada bulk cairan/ } \\
\text { substrat }\end{array}$ & $\mathrm{kg} / \mathrm{m}^{3}$ \\
\hline$S_{s o}$ & $\begin{array}{l}\text { konsentrasi air limbah } \\
\text { masuk biofilter }\end{array}$ & $\mathrm{kg} / \mathrm{m}^{3}$ \\
\hline$X_{b}$ & $\begin{array}{l}\text { konsentrasi biomassa } \\
\text { pada effluent }\end{array}$ & $\mathrm{kg} / \mathrm{m}^{3}$ \\
\hline$Y_{X / S}$ & $\begin{array}{l}\text { yield biomassa } \\
\text { terbentuk per substrat } \\
\text { yang digunakan }\end{array}$ & $\begin{array}{c}\mathrm{kg} \\
\text { biomassa/ } \\
\text { kg substrat }\end{array}$ \\
\hline$K_{s}$ & $\begin{array}{l}\text { kejenuhan } \\
\text { mikroorganisme } \\
\text { terhadap substrat }\end{array}$ & $\mathrm{kg} / \mathrm{m}^{3}$ \\
\hline$q_{H}$ & $\begin{array}{l}\text { kecepatan } \\
\text { pertumbuhan } \\
\text { mikroorganisme }\end{array}$ & hari $^{-1}$ \\
\hline
\end{tabular}

Tabel 1. Keterangan variabel model

Tabel 2. Data spesifikasi, properti biofilter dan

\begin{tabular}{|c|c|c|}
\hline Lambang & Arti & Nilai \\
\hline \multicolumn{3}{|c|}{ Data spesifikasi biofilter } \\
\hline$T$ & tinggi & $1 \mathrm{~m}$ \\
\hline$\varnothing$ & diameter & $12,7 \mathrm{~cm}$ \\
\hline$V_{t}$ & volume total & $12,67 \mathrm{~L}$ \\
\hline \multicolumn{3}{|c|}{ Data properti biofilter } \\
\hline$L$ & $\begin{array}{l}\text { tinggi media/bahan } \\
\text { isian }\end{array}$ & $90 \mathrm{~cm}$ \\
\hline$A_{c}$ & cross-sectional area & $126,61 \mathrm{~cm}^{2}$ \\
\hline$V$ & volume biofilter & $11 \mathrm{~L}$ \\
\hline \multicolumn{3}{|c|}{ Konstanta mode/(16) } \\
\hline$f_{a c}$ & $\begin{array}{l}\text { porositas media } \\
\text { isian }\end{array}$ & 0,87 \\
\hline$a_{s}$ & $\begin{array}{l}\text { luas biofilm pada } \\
\text { permukaan media }\end{array}$ & $200 \mathrm{~m}^{2} / \mathrm{m}^{3}$ \\
\hline$L_{f}$ & ketebalan biofilm & $2 \mathrm{~mm}$ \\
\hline$\eta_{e}$ & effectiveness factor & 0,5 \\
\hline
\end{tabular}
nilai konstanta

Dari penjabaran persamaan diferensial di atas selanjutnya diperoleh hubungan antara konsentrasi limbah keluar biofilter ( $\mathrm{Sse}$ ) terhadap kecepatan beban hidraulik (HLR) (pers. 3).

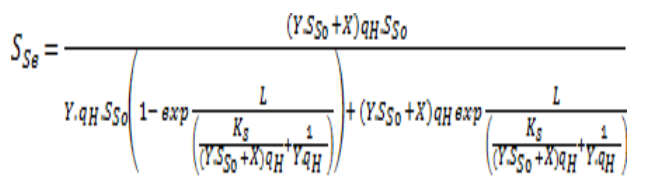

dengan:

$$
X=\left(\frac{a s . A c}{F}\right) \eta_{e} \cdot X_{b} \cdot L_{f}
$$




$$
Y=\left(\frac{f_{a c} \cdot A c}{F}\right) Y_{x / s}
$$

Dari parameter kecepatan aliran limbah $(F)$ selanjutnya dapat diukur nilai kecepatan beban hidarulik (HLR) dan kecepatan pengurangan subtrat (substrat reduction rate/SRR) untuk mengetahui hubungan keduanya dan juga terhadap persen limbah tersisihkan. Reduction rate menyatakan banyaknya substrat yang terdegradasi oleh mikroorganisme setiap waktu pada elemen volume biofilter, yang jenisnya tergantung pada reaksi penyisihannya. Untuk penyisihan amonia disebut nitrification reduction rate (NRR), sedangkan untuk penyisihan fosfat disebut denitrification reduction rate (DRR).

Ketiga persamaan operasional biofilter tersebut dirumuskan sebagai berikut:

$$
\begin{aligned}
& H R L=q=\frac{F}{A_{c}} \\
& S R R=\frac{\left(S_{S 0}-S_{S e}\right) \cdot F}{V} \\
& \% \text { Substrat tersisihkan }=\left[1-\frac{S_{S e}}{S_{S 0}}\right] \times 100 \%
\end{aligned}
$$

\section{HASIL DAN PEMBAHASAN}

Profil penurunan konsentrasi masingmasing jenis limbah pada berbagai variasi $\mathrm{HRL}$ dinyatakan pada Gambar 3 dan Gambar 4. Dari grafik tersebut terlihat bahwa proses penyisihan limbah amonia dan fosfat berhasil karena konsentrasi effluent lebih rendah dari nilai baku mutu lingkungan untuk limbah cair sesuai Permen Lingkungan Hidup dan Kehutanan Nomor P.68 Tahun 2016 tentang Baku Mutu Air Limbah Domestik mensyaratkan bahwa batas konsentrasi amonia untuk limbah domestik yang diizinkan untuk dibuang adalah 10 ppm.



Gambar 3. Hubungan antara konsentrasi effluent amonia terhadap HLR

Untuk limbah amonia, pada HLR di atas $0,74 \mathrm{~m}^{3} / \mathrm{m}^{2} /$ hari menunjukkan konsentrasi effluent sudah berada di atas nilai baku mutu. Hal ini menjadi dasar parameter operasional HLR untuk keamanan pembuangan limbah amonia ke lingkungan.

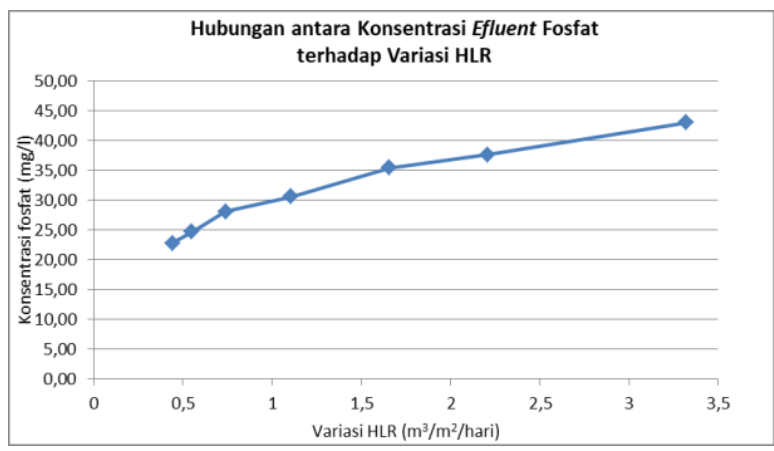

Gambar 4. Hubungan antara konsentrasi effluent fosfat terhadap HLR

Adapun untuk limbah fosfat, terlihat bahwa penurunan konsentrasi limbahnya tidak terlalu signifikan dengan berbagai perlakuan HLR. Hal ini mengindikasikan bahwa di dalam biofilter anaerob proses biodegradasi fosfat oleh mikroorganisme relatif stabil pada kecepatan beban hidraulik rendah.

\subsection{Pengaruh Hydraulic Loading Rate (HLR) terhadap Substrat Reduction Rate (SRR)}

Hubungan antara HLR dengan SRR untuk amonia (nitrification reduction rate [NRR]) dan fosfat (denitrification reduction rate [DRR]) tersaji pada Gambar 5 dan Gambar 6.

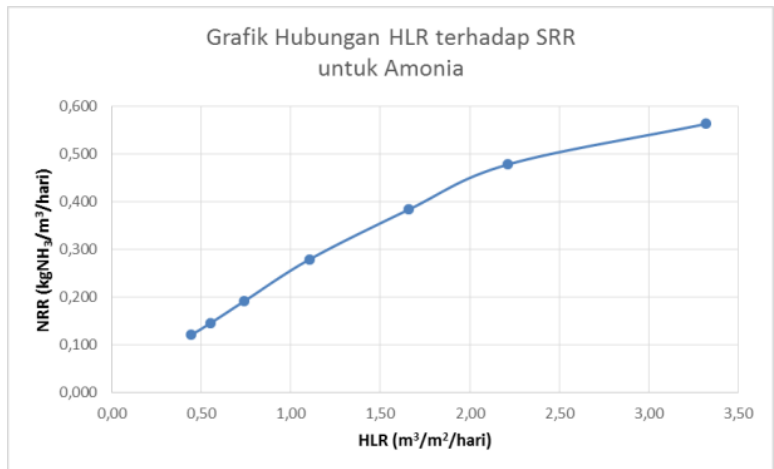

Gambar 5. Hubungan antara HLR terhadap NRR

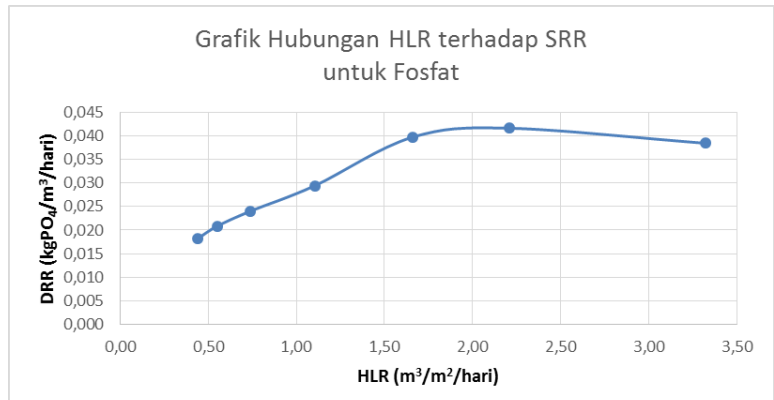

Gambar 6. Hubungan antara HLR terhadap DRR

Dari kedua grafik tersebut menunjukkan bahwa kecepatan degradasi substrat/limbah oleh mikroorganisme dipengaruhi oleh kecepatan beban hidraulik air limbah yang masuk ke dalam biofilter. Semakin besar nilai 
HLR semakin besar pula kecepatan pengurangan substrat amonia maupun fosfat.

Untuk limbah amonia, pada panjang reaktor $90 \mathrm{~cm}$, hubungan antara NRR dan HLR konsisten linear. Ini menunjukkan bahwa penambahan HLR belum mengakibatkan kejenuhan nilai NRR (stationer phase). Adapun pada limbah fosfat, untuk HLR $2,21 \mathrm{~m}^{3} / \mathrm{m}^{2} /$ hari menunjukkan kondisi pertumbuhan mikroorganime yang tumbuh di dalam biofilter telah memasuki fase stasioner. Bahkan untuk nilai HLR di atas $3,32 \mathrm{~m}^{3} / \mathrm{m}^{2} /$ hari justru mengurangi kecepatan degradasi limbah. Hal ini menunjukkan bahwa mikroorganisme yang tumbuh di dalam sistem biofilm mengalami sloughing.

Sloughing adalah peristiwa terlepasnya koloni mikroorganisme yang menempel pada media tumbuh sebagai akibat terlalu derasnya aliran substrat yang masuk ke dalam reaktor ${ }^{(17)}$. Peristiwa seperti ini sangat dihindari dalam proses pengolahan limbah. $\mathrm{Hal}$ ini akan mengurangi atau bahkan bila terlalu deras dapat membuang mikroorganisme yang tumbuh dalam reaktor. Oleh karena itu, dalam penentuan operasional reaktor, parameter ini perlu dicari untuk mengetahui batasan optimal dalam mendegrasi limbah.

\subsection{Pengaruh Hydraulic Loading Rate (HLR) terhadap Persentase Limbah Tersisihkan}

Hubungan antara HLR dengan presentase limbah tersisihkan untuk amonia dan fosfat tersaji pada Gambar 7 dan Gambar 8.

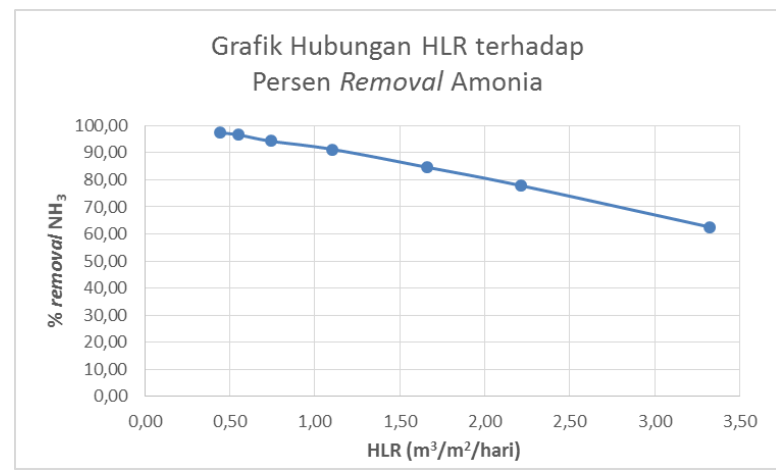

Gambar 7. Hubungan antara HLR terhadap persen amonia tersisihkan

Dari gambar penyisihan amonia terlihat bahwa pengujian reaktor nitrifikasi terhadap variasi HLR sampai dengan $1,11 \mathrm{~m}^{3} / \mathrm{m}^{2} /$ hari masih bisa menyisihkan polutan di atas $90 \%$. Sedangkan untuk reaktor denitrifikasi menunjukkan bahwa pada HLR terendah, yaitu $0,44 \mathrm{~m}^{3} / \mathrm{m}^{2} /$ hari kemampuan menyisihkan limbah fosfat hanya $50 \%$. Hal ini menunjukkan pula bahwa untuk penyisihan limbah fosfat memerlukan volume reaktor yang lebih besar.

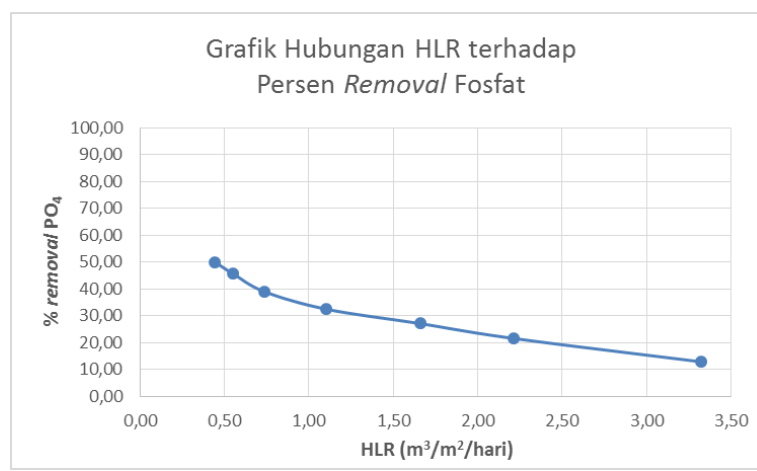

Gambar 8. Hubungan antara HLR terhadap persen fosfat tersisihkan

Comeau dan Wentzel dalam Grady et al.(6) mengatakan bahwa mekanisme penyisihan fosfat melalui dua tahap, yaitu di dalam reaktor anaerob terjadi proses pelepasan/release fosfat dan di dalam reaktor aerob terjadi pengambilan/uptake fosfat. Proses pelepasan yang terjadi di reaktor anaerob diakibatkan oleh asimilasi asam lemak rantai pendek (VFA) menjadi polihidroksi-butirat (PHB) di dalam mikroorganisme pengakumulasi polifosfat $\left(\mathrm{PAO}_{s}\right)$. Proses tersebut membutuhkan energi yang diambil dari hidrolisis ATP menjadi ADP dari proses metabolisme bakteri.

ATP atau Adenosin Tri-Fosfat adalah unit energi sel. ATP merupakan molekul pembawa energi yang digunakan untuk aktivitas organisme. Sebuah molekul ATP terdiri dari tiga bagian, yaitu sebuah cincin ganda karbon dan nitrogen yang disebut adenine, karbohidrat lima karbon yang disebut ribose, dan tiga unit fosfat yang ketiganya diikat bersama oleh ikatan kovalen. Meskipun digolongkan sebagai molekul berenergi tinggi, ikatan kimianya labil dan mudah melepaskan gugus fosfatnya. Pada saat sel membutuhkan energi, ATP dapat segera dipecah melalui reaksi hidrolisis (menjadi ADP) dan terbentuk energi yang sifatnya mobile sehingga dapat diangkut dan digunakan oleh seluruh bagian sel tersebut.

Adanya proses asimilasi oleh $\mathrm{PAO}_{s}$ mengakibatkan rasio ATP/ADP menurun sehingga untuk mensintesis ulang ATP diambilkan dari simpanan polifosfat. Adapun sisa hidrolisis ATP (dalam bentuk $\mathrm{P}_{\mathrm{i}}$ ) akan dilepaskan oleh bakteri ke dalam bulk cairan.

Selanjutnya, ketika limbah fosfat dan mikroorganisme memasuki reaktor aerob akan tersedia oksigen sebagai aseptor elektron. $\mathrm{PAO}_{\text {s }}$ akan bermetabolisme menggunakan simpanan PHB sebagai sumber karbon dan energi. Proses metabolisme akan dihasilkan ATP dan untuk penyediaan fosfat $\mathrm{PAO}_{s}$ akan mengambil/uptake fosfat dari limbah cair.

Dari pengkajian tersebut diketahui bahwa proses penyisihan fosfat yang dilakukan pada 